\title{
The Influence of Socio-Educational Factors in the Selection of Contents for Fullfilling Free Time of High School Students
}

\author{
Doc.Dr. Besa Havziu \\ Pedagogical Faculty, University of Tetovo, Republic of Macedonia \\ Doc. Dr. Lulzim Mehmedi \\ Pedagogical Faculty, University of Tetovo, Republic of Macedonia \\ Makfirete Ameti \\ Pedagogical Faculty, University of Tetovo, Republic of Macedonia
}

\begin{abstract}
Starting from the fact that man is a social being, social environment has a big importance in the whole personality formation and development. Even though there are views according to which geographical and climate factors can also influence a person's character, yet they are not the crucial ones. A social environment where the influence of: family, school, peers, mass media, different organizations and those alike is strongly expressed, enables the child as a biological being to gradually grow into a social being through gaining knowledge, habits, abilities etc. The pedagogical meaning of free time is not seen in the organisation of the free activities but in the different factors of institutional character, which more or less can help the shaping of free time with the creation of practical opportunities for its implementation. In this paper, the factors and their influence on the selection of the content of free time at high school respondents will be analysed. More precisely, we will analyse the respondents' views and opinions about the factors which will determine the selection of free time content, if there are differences compared according to the influence, which of them appear as decisive factors and if there are gender differences from the aspect of the factors influence in the selection of free time activities and contents. In the problem researching process we decided to apply: inductive method, deductive method and comparison method.
\end{abstract}

Keywords: free time, factors, school as a factor, family as a factor, social environment as a factor, student, free activities, culture and gender differences

\section{Introduction}

The objective situation in Rep. of Macedonia, in terms of research on the extent of the impact of educational and social factors in the choice of the contents for fulfilling the free time of the secondary education students, is characterized by absence (lack) of adequate relevant knowledge about the occurrence which is subject of research of this work. Because of this state, there are several general and specific reasons that require the need for more sustained exploration of this problem. In the approach to the study of this phenomenon is necessary to achieve the required scientific consistency in the application of the research procedures, collection and processing of empirical data, analysis, interpretation and explanation of the results, drawing adequate conclusions based on the application of the appropriate methodology which will provide for these relations, to be explained from scientific aspect. Namely, the phenomenon of the impact of various factors in determining the content of the free time of the young people is extremely complex phenomenon which requires special examination and consideration of the extent of impact of those factors. Due to insufficient theoretical and empirical knowledge about the problem, we believe it is beneficial for our society to explore the factors that influence the choice of content with which secondary school students fulfil their free time. 
This paper will analyse the influence of the family, school, mass culture, peers, partners and autonomy in the choice of content at the secondary school students in Macedonia. To effectuate the purpose of the research, one general and one auxiliary hypothesis is set.

\section{General hypothesis:}

There are differences in the degree of influence of the various factors (family, friends, school, the opposite sex and mass culture) which determine the content (activities) of the free time.

\section{Auxiliary hypothesis:}

The sudents of different genders differ among themselves in the attitudes and opinions regarding the impact of the factors in the choice of content (activities) in their free time.

\section{FACTORS FOR ORGANISING FREE TIME}

Considering the fact that man is a social being, the social environment is of great importance in the overall development and formation of the personality. Although there are views according to which geographical and climatic factors can affect a person's character, yet - they are not decisive. The social environment in which the strong influence of the family, school, peers, mass media, various organizations, etc., allows the child as a biological creature to gradually grow into social being, through the acquisition of knowledge, habits, skills, etc. ${ }^{1}$

Pedagogical importance of the free time is not seen in organizing free time activities themselves but in the various factors of an institutional nature that more or less can help shaping their free time by creating practical opportunities for its implementation. ${ }^{2}$

There are numerous factors that affect the organization and way of spending free time at children and young people starting with the family, preschool, school, numerous institutions in the field of culture, science, and mass media of all types and so on. Each of these factors has its own specific educational potential and each of them has a decisive influence on the development of young people in the educational environment and the type of education in the individual free time activities.

High school students, given that they undergo major development of their personality, certainly require assistance and understanding from the family, school or wider community, to meet their internal needs through organized activities to be realized in their free time. But if their demands are not met by the aforementioned institutions, then they are simply forced to meet their own needs by performing a variety of unorganized and under-constructive activities. "Human rights are basic standards that a country must ensure and provide for each individual. Besides satisfying the biological needs, they also include many other living conditions, each individual should develop the potential to meet their needs and so on."3

In this sense we may say that free time is part of life for every individual in the society, without exception or distinction between ethnicity, gender, religion, age, etc. Therefore the free time of students is fulfilled in accordance with their needs and interests, but unlike adults, their free time varies in its length and content. Because of that, we considr that it would be correct for the various factors to take particular care to orient the youth for the proper organization of the free time, in order to avoid any unwanted behaviour that may occur as a result of lack of constructive use of the free time.

For the use, organizing and fulfilling the free time, a range of organizations, institutions, facilities, services and individuals should take care. Their role is particularly defined and specific, but the strength of affect is different.

Free time takes part into all areas of life of the people: the area of work, production, family life, material and spiritual values, physical education, manual and intellectual activities, technical - technological area, the area of science, art, social life and other.

\footnotetext{
${ }_{1}^{1}$ Popova - Koskarova, R. (2004). Вовед во педагогија. Skopje: Grafik mak print DOOEL Eksport-Import, pg. 105

${ }^{2}$ Barakoska, А. (2005). Педагогија на слободното време. Skopje: Dominant, pg.148

3 llievski, G.(2001). Воспитанието и образованието за правата на децата во PM. Sveti Nikole: MCSP , pg. 25
} 
Contemporary society must take into account not only the quantitative assurance of free time, but also the creation of social factors that help in various ways, direct, advice and enable usage of the free time. Nowadays, that is what almost every society already does; there is a whole range of factors, which on one way or another, and more or less organized and with different intentionality, take care of the way how to organize free time. ${ }^{1}$

In this context, the author V. Janković, grouped all factors into five categories. The first group lists the educational institutions which, as separate institutions according to the pedagogical intentionality, are most renowned for the care of all areas of educational actions, as well as the area of free time and its activities. These are: preschool institutions, schools (primary and secondary), children and youth summer camps, school dorms and institutions for adult education.

The second group of factors are less characterized by institutionality, and with some in the programs of work even the intentionality is not clearly expressed. There are: family, children, youth and social organizations.

The third group of factors are various facilities like: playgrounds, nursery schools, summer camps, swimming pools, resorts, camping sites, clubs, dorms, culture centres, mountain huts and so on.

The fourth group is consisted of institutions of general cultural, educational, informative and entertaining character, such as theatres, cultural and artistic exhibitions, libraries, museums, television and radio stations, movie theatres, record companies, social universities, etc.

The fifth group is consisted of factors in the area of "functional" education, such as: events, performances, life in public places (on the street, in parks, public bars, shops) etc. ${ }^{2}$

Therefore the activities of free time and the pedagogical activities can be classified as multidisciplinary coordinated activities. The carriers of these activities and the factors of education in the free time are: family, preschool, school, extracurricular institutions and associations such as the various sports, scientific, technical, cultural and other associations. The organizations that unite children and young people in their free time are numerous. With their active programs and content they attract children and young people. Among the factors and holders of the educational action in free time, the following stand out in particular: the media, daily press, cinema, theatre, radio and television, social networks, cultural centres, clubs of information experts, libraries, reading rooms, galleries, museums, concert halls etc.

According to the above we believe that the factors that determine the organization and the way students spend their free time are many, and can be grouped as follows:

The family as a factor (basic social institution)

Factors which directly contribute to the organization and education of the free time, educational institutions such as:

Preschool institutions, children's organizations

School (primary and secondary schools)

Mass culture (media, social networks, etc.)

Social organizations, cultural and other public institutions and organizations as factors in the organizing the free time of young people (students), and

Peers as factor

In addition in the interest of this paper we will elaborate more broadly the impact of certain factors on the education and socialization of young people in their free time. We will present in detail some of the results obtained by examination (survey) of the attitudes and opinions of secondary school students in Tetovo and Skopje, regarding the impact of various factors in the selection of free time activities.

Herebelow is the analysis of the attitudes and opinions of respondents about the factors that determine the choice of free time contents. This section of the questionnaire is consisted of six individual claims, followed by the assessment scale of

\footnotetext{
1 Plenković, J. (2000).Slobodno vrijeme mladeži. Rijeka: Sveučilište u Rijeci

2 Janković, V. (1976). Slobodndo vrjeme u suvremenoj pedagoškoj teoriji i praksi. Zagreb:Pedagoško-književni zbor
} 
Likert type, with the same four standard categories for locating the answer (never, occasionally, often, always). At first, we were not interested in the gender structure of the answers to this question, given the presumed relevant position of this variable in terms of socio-cultural moment characteristic for our environment.

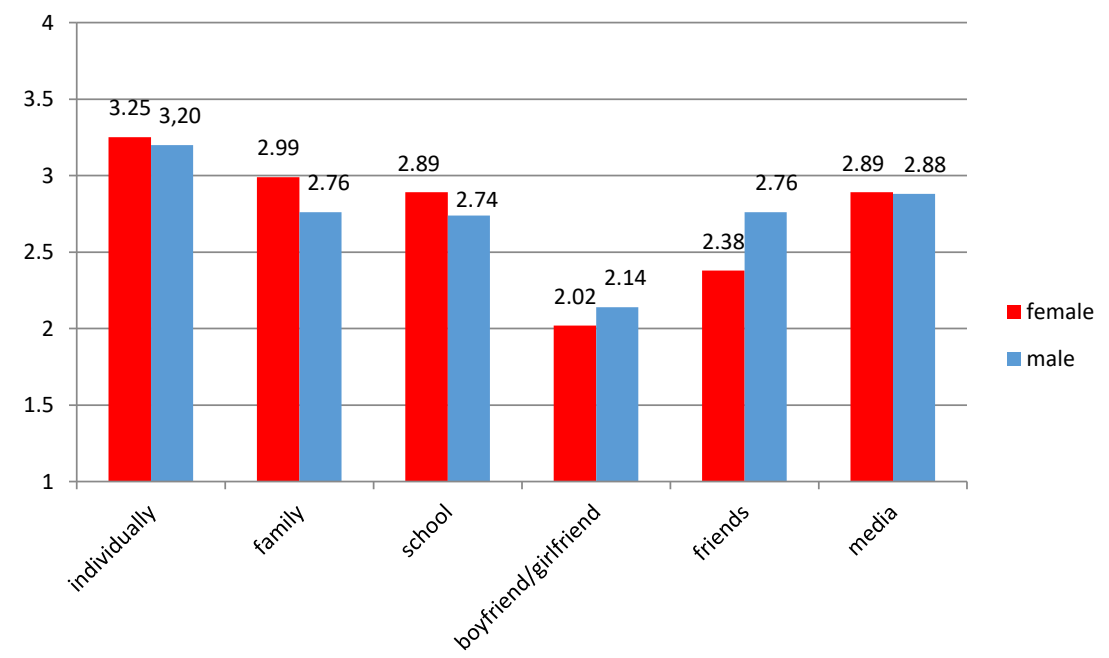

Figure No. 5.1.

Gender and factors of the content in the free time

From the attached graphical Figure No. 5.1 it can be seen that, in general, girls value the impact of family and school above the impact by their peers, while the boys emphasise the influence by friends and the partner (girlfriend). The differences in the assessment of impacts of their own choice and the mass media are insignificant.

Statistical intersection usually calculated by Mann-Whitney test, shows that a good portion of these observations are significant (Table No. 5.1.). In particular, girls statistically appreciate the influence of family significantly higher $(Z=-3,973$, $p<0,01)$ and the school $(Z=-3,085, p<0,01)$. Boys, on the other hand, appreciate higher the influence of friends $(Z=-$ $4,563, p<0,01)$.

\section{Table No. 5 a.}

Gender and the factors of choice of contents in the free time (Mann-Whitney Test)

\begin{tabular}{|c|c|c|c|c|c|c|}
\hline \multicolumn{2}{|l|}{$\begin{array}{c}\text { Content of the free time } \\
\end{array}$} & Main rank & $\sum$ of ranges & 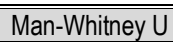 & $\overline{z Z}$ & $p$ \\
\hline \multirow{2}{*}{ I select individually } & female & 239,26 & $\begin{array}{l}57,901,50 \\
\end{array}$ & \multirow{2}{*}{28498,500} & \multirow[t]{2}{*}{ 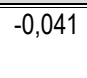 } & \multirow[t]{2}{*}{0,967} \\
\hline & male & 233,74 & 56579,50 & & & \\
\hline \multirow{2}{*}{$\begin{array}{l}\text { My family is directing } \\
\mathrm{me}\end{array}$} & female & 261,63 & 63313,50 & \multirow[t]{2}{*}{23443,500} & \multirow[t]{2}{*}{$-3,973$} & \multirow[t]{2}{*}{$0,000^{* *}$} \\
\hline & male & 217,92 & 51646,50 & & & \\
\hline \multirow{2}{*}{$\begin{array}{l}\text { The school is directing } \\
\text { me }\end{array}$} & female & 256,16 & 61990,00 & \multirow[t]{2}{*}{24767,000} & \multirow[t]{2}{*}{$-3,085$} & \multirow[t]{2}{*}{$0,002^{* *}$} \\
\hline & male & 223,50 & 52970,00 & & & \\
\hline \multirow{2}{*}{ Influence of the partner } & female & 234,02 & 56399,00 & \multirow[t]{2}{*}{27238,500} & \multirow[t]{2}{*}{$-0,920$} & \multirow[t]{2}{*}{0,358} \\
\hline & male & 245,07 & 58082,00 & & & \\
\hline \multirow{2}{*}{ Influence of friends } & female & 212,48 & 51208,00 & \multirow[t]{2}{*}{22047,000} & \multirow[t]{2}{*}{$-4,563$} & \multirow[t]{2}{*}{$0,000^{\star *}$} \\
\hline & male & 266,97 & 63273,00 & & & \\
\hline \multirow{2}{*}{ Influence of media } & female & 242,47 & 58677,50 & \multirow[t]{2}{*}{28079,500} & \multirow[t]{2}{*}{$-0,444$} & \multirow[t]{2}{*}{0,657} \\
\hline & male & 237,48 & 56282,50 & & & \\
\hline
\end{tabular}


From the collected data it is actually perceived the recent stereotype in our culture of life where females as opposed to males in most cases, still prove to be more obedient and more disciplined when it comes to family and school.

This means that there are grounds for accepting research auxiliary hypothesis, which states:

\section{"The sudents of different genders differ among themselves in the attitudes and opinions regarding the impact of the factors in the choice of content (activities) in their free time."}

Hereby follows further analysis of the attitudes and opinions of respondents about the factors that determine the choice of free time contents. The interviewed students at an average (Figure no. 5) grant the highest weight to the independent selection of content for free time (3.23). Noticeably though with less impact yet as clear engines are also: media (2.89), family (2.88) and school (2.82) and the least influence is by friends (2.57) and partner (2.08).

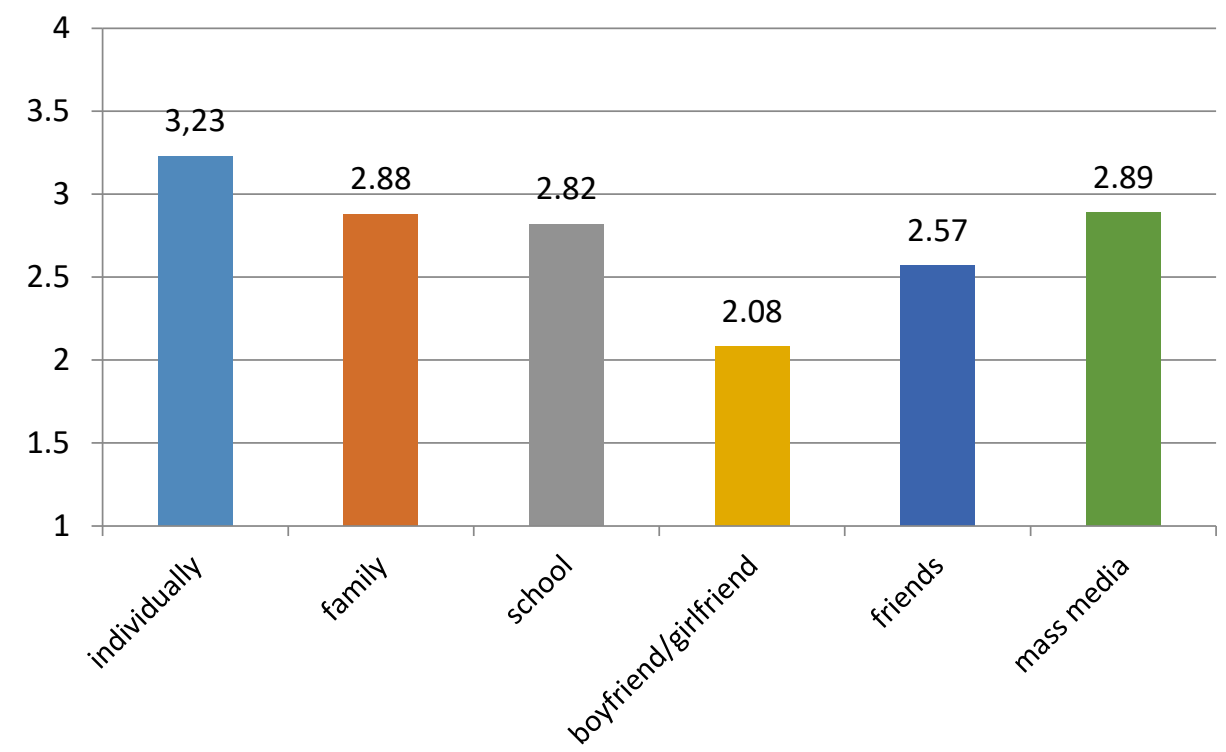

Figure No. 5.

Who has influence on the content of the free time (avverage rang)

Given that the data from this issue are based on given rankings (as well as any evaluation of Likert type), the most appropriate procedure for statistical calculation of any differences in the average ranking among the six factors of choice of content for free time is Friedman test, a kind on non-parametical counterpart of the one-way ANOVA for repeated measures. The calculated value of Friedman test (Table No. 5$)$ is statistically significant $\left(X^{2}=510,721 ; d f=5, p<0,01\right)$

\section{Table No. 5.}

Who has influence on the content of the free time (Friedman Test)

\begin{tabular}{||l||l|l|l|l|l||}
\hline Content of the free time & $\mathrm{N}$ & major rank & $X^{2}$ & $\mathrm{df}$ & $\mathrm{P}$ \\
\hline \hline I select individually & \multirow{3}{*}{476} & 4,54 & & & \\
\hline My family is directing me & 3,76 & \multirow{3}{*}{510,721} & \multirow{3}{*}{5} & $0,000^{* *}$ \\
\hline The school is directing me & & 3,57 & & & \\
\hline Influence of the partner & 2,25 & & & \\
\hline
\end{tabular}




\begin{tabular}{||l||l|l|l|l||}
\hline Influence of friends & 3,12 & & & \\
\cline { 1 - 2 } Influence of mass media & 3,76 & & & \\
\hline
\end{tabular}

From the obtained results it is obvious that with the students of the secondary education, the principle of free choice is respected, by the fact that we have higher claim in the opinion (Content of free time are choosen in an independent manner), but their orientation is also influenced by other factors such as family, school and mass media, regardless that appear in lower ranks, as well as their peers.

Thus we can say that there are grounds for accepting research general hypothesis, in other words, it can be concluded that there are differences in the degree of influence of various factors (individual choice, family, friends, school, the opposite sex and mass culture) that determine in the contents of the free time.

\section{Conclusion}

The analysis of the theoretical debates on this problem as well as empirical data that we came up with through the research survey of secondary school students, enabled us to clarify some aspects of the appearance that we have investigated. According to the obtained results it is obvious that secondary school students, in larger number, select the activities in their free time in free manner, or according to their own choice - which can b seen in the Table No. 5, where from the six offered factors (agents) which have influence on the selection of free time activities, i.e. factors that guide students in the selection of free time activities, the highest level is awarded to independent selection of content in their free time (4.54).

Furthermore, we come to the conclusion that among secondary school students, the principle of free choice in choosing leisure time activities is respected, which generally only guarantees the essence of free time and the performance of the activities. Hence, the presence of freedom is highly valuated anong young people.

On the other hand, when analyzing the impact of other educational and social factors in the choice of content for the free time, such as family, school, partner, friends and mass culture, from the obtained results, we can come to the conclusion that originally as the most important even though in lower rank than the own choise, but still dominant factors are: family and mass culture, with the same main rank (3.76) as presented in Table No. 5. In the third category of impact appears the school as a factor, with degree of valuation (3.57), followed by the influence of friends, which appears at degree level of (3.12), while the lowest ranked is the influence of the partner with degree of valuation (2.25).

According to the above empirical data we can conclude that there are differences in the impact of educational and social factors in the choice of content for free time among secondary school students, but as decisive factors (in addition to their own choice) however emerge: family, mass culture and school. Somehow surprising is the fact that even though the secondary school students are in a period of rapid development of their personality, however in organizing activities in their free time their partner does not affect greatly. Whereas when it comes to gender differences in terms of the impact of various social factors in determining the free time activities for secondary school students, we have already dominant differences in ranking of the same. Females apparently have more influence by the family and school (as seen from the above attached Table No. 5.1), while males as dominant influence in the choice of activities during free time have their friends.

Therefore, we can conclude that female secondary education students are more open, closer and more inclined to the family, they somehow tent to appear as more mature persons at this stage of their development, and that also reflects the socio-cultural point of our environment in the construction of cultural values, values that increasingly imposed on women. Thus as decisive factors in the choice of content in his free time of girls appears the family and school. Somehow in this segment boys are as if they are more left to themselves in the choice of content free fime, and care more about the fact how they will be assessed and valued by their friends. Whereupon, we can conclude that for the boys as a decisive factor appear their friends.

Base on what we have ellaborated in this paper, we can conclude that our general hypotheses, stating: "There are differences in the degree of influence of the various factors (family, friends, school, the opposite sex and mass culture) which determine the content (activities) of the free time"as well as the auxilary hypothesis according to which: "The sudents of different genders differ among themselves in the attitudes and opinions regarding the impact of the factors in the choice of content (activities) in their free time"are confirmed. 
The conclusions of this research should be upheld in direction of further enhancement and enrichment the free time of young people, with organized and structured activities of the different factors that will orient towards correct and cultural use of free time. All factors for the organization of free time, can contribute to reducing the unwanted behaviour among young people, with their joint action in the organization free time students can achieve great success in shaping the culture of free time among young people. Thus, any kind of activities that would be of interest for the students, and which orient the aforementioned factors - contribute to the enrichment of their way of life and if they are seriously engaged and caring for the free time and content of free time of young people, the will be less space left for the performing socially unacceptable behaviour among them.

Therefore, we recommend the following: Regardless of the fact that there are certain differences in the degree of influence of various factors in the choice of content for fulfilling the free time for the scondary school students, each of these factors should be seriously concerned with the question of free time of young people and their influence not shoulnd be underestimated, but rather all factors have equal engagement towards the orientation of the youth people to properly fulfill their free time, by providing premises for developing their inner potentials. Because the choice of free time activities for secondary school students provides for opportunities for the full development of their personality, encompassing all educational components. "Every child has some ability and talent", but each talent requires space to develop, and if that space is not established in their free time, then there is a risk of losing the talent, development and healthy life of a young person.

Bibliography:

[1] Barakoska, A. (2005). Педагогија на слободното време. Skopje: Dominant.

[2] Ilievski, G.(2001). Восnитанието и образованието за правата на децата во PM. Sveti Nikole: MCSP.

[3] Plenković, J. (2000).Slobodno vrijeme mladeži. Rijeka: Sveučilište u Rijeci.

[4] Popova - Koskarova, R. (2004). Вовед во педагогuja. Skopje: Grafik mak print DOOEL Eksport-Import.

[5] Janković, V. (1976). Slobodndo vrjeme u suvremenoj pedagoškoj teoriji i praksi. Zagreb:Pedagoško-književni zbor. 